\title{
PEMANFAATAN RINFODOCS SEBAGAI MEDIA PENYUSUNAN DRAFT LAPORAN DALAM PROSES BIMBINGAN TUGAS AKHIR PADA PERGURUAN TINGGI
}

\author{
Ary Budi Warsito ${ }^{1}$ \\ Muhamad Yusup ${ }^{2}$ \\ Erlita Rasdiana ${ }^{3}$ \\ e-mail :arybudiwarsito@raharja.info,yusup@raharja.info,erlita@raharja.info
}

Diterima : 20 Agustus 2014 / Disetujui : 04 September 2014

\begin{abstract}
Learning in Higher Education System is identical to a conventional manner. This is evident from the way the students in final report. In the process of guidance, the students are still accustomed to the draft report in the form of a printout of the Lecturer. Lecturer then perform correction on the draft report printed sheet, so if there are errors in the writing of the report, the student is required to revise and reprint subsequently submitted to the Lecturer for further corrected. This is very inefficient in the guidance process, due to the use of paper that is not a little, due to the printout draft report before and after the revision. Final report guidance process is the same as running in Raharja University. Then to support that learning systems can make it easier for students and the Lecturer is to utilize RinfoDocs as a medium to support the process guidance Final report. RinfoDocs is one feature in RinfoDrive provided by Rinfo. While Rinfo is a platform using Google's Gmail service provided exclusively by the Pribadi Raharja (Civitas Academic). Because using the Google email platform. With the RinfoDocs learning process can be done online because it can be done anywhere and anytime. Through the use of RinfoDocs expected to facilitate the process of drafting the final report guidance on the college.
\end{abstract}

Keywords: RinfoDocs, Final Report, Guidance.

\begin{abstract}
ABSTRAK
Sistem pembelajaran pada Perguruan Tinggi masih identik dengan cara konvensional. Hal ini terlihat dari cara mahasiswa dalam melakukan bimbingan Tugas Akhir. Dalam proses bimbingan, para mahasiswa masih terbiasa memberikan draft laporan berupa print outkepada Dosen Pembimbing. Dosen Pembimbing kemudian melakukan pengoreksian pada lembaran draft laporan yang tercetak, sehingga jika terdapat kesalahan dalam penulisan laporan tersebut maka mahasiswa diharuskan untuk melakukan revisi dan mencetaknya kembali selanjutnya diserahkan kepada Dosen Pembimbing untuk dikoreksi lebih lanjut. Hal ini tentu sangat tidak efisien dalam proses bimbingan, dikarenakan penggunaan kertas yang tidak sedikit, disebabkan oleh pencetakkan ulang draft laporan sebelum dan sesudah direvisi. Proses bimbingan laporan Tugas Akhir tersebut sama halnya dengan yang sedang berjalan di Perguruan Tinggi Raharja. Maka untuk mendukung agar sistem pembelajaran dapat lebih memudahkan mahasiswa maupun Dosen Pembimbing adalah dengan memanfaatkan RinfoDocs sebagai media untuk mendukung proses bimbingan laporan Tugas Akhir. RinfoDocs merupakan salah satu fitur ada di RinfoDrive yang disediakan oleh Rinfo. Sedangkan Rinfo adalah sebuah layanan gmail menggunakan platform Google yang disediakan khusus oleh Perguruan Tinggi Raharja untuk Pribadi Raharja (Civitas Akademik). Karena menggunakan platform email Google. Dengan adanya RinfoDocs proses pembelajaran dapat dilakukan secara online karena dapat dilakukan dimanapun dan kapanpun. Melalui pemanfaatan
\end{abstract}


RinfoDocs diharapkan dapat memudahkan proses penyusunan draft laporan dalam proses bimbingan Tugas Akhir pada perguruan tinggi.

Kata Kunci : RinfoDocs, Laporan Tugas Akhir, Bimbingan.

\section{PENDAHULUAN}

Teknologi informasi terus berkembang sesuai dengan kebutuhan dan kegiatan organisasi dalam menghadapi persaingan yang begitu ketat. Saat ini informasi tak lagi dapat diserap dengan mengandalkan perangkat-perangkat yang masih kuno dan serba manual, oleh karena itu peran komputer sangatlah penting dalam memberikan suatu solusi dan merupakan alat bantu yang cukup baik dalam memperbaiki sistem yang belum optimal. Selain itu, dengan adanya komputerisasi dapat mendukung dalam peninggkatan mutu pelayanan suatu organisasi sehingga dapat meningkatkan perkembangan organisasi tersebut. Selain itu, Kecanggihan teknologi informasi dan komunikasi telah memungkinkan terjadinya pertukaran informasi yang cepat tanpa terhambat oleh batas ruang dan waktu.

Sebagai salah satu lembaga pendidikan yang bergerak di bidang IT (Information Technology), Perguruan Tinggi Raharja terus berinovasi dalam menciptakan media sistem informasi untuk kebutuhan sehari-hari. Maka untuk itu dalam proses pembelajaran juga harus mengalami perubahan yang signifikan kearah yang lebih modern dan canggih, tidak hanya dilakukan secara konvensional akan tetapi sudah berbasis kepada teknologi informasi.

Perguruan Tinggi Raharja memiliki visi yaitu meningkatkan kualitas pendidikan. Dalam rangka mencapai visi tersebut, Perguruan Tinggi Raharja senantiasa berupaya melaksanakan visinya dalam bentuk penyelenggaraan program-program studi yang menunjang pengembangan dan penerapan Teknologi Informasi dalam berbagai bidang ilmu.

Salah satu inovasi yang dilakukan Perguruan Tinggi Raharja adalah dengan mengubah sistem pembelajaran yang semula berjalan dengan cara konvensional (manual) menjadi modern (online). Dengan sistem pembelajaran online diharapkan dapat meningkatkan mutu pendidikan pada Perguruan Tinggi Raharja, terutama dalam proses bimbingan laporan Tugas Akhir.

Bimbingan laporan Tugas Akhir merupakan suatu proses pembelajaran yang dilakukan oleh mahasiswa dengan dose pembimbingnya yang dapat dilakukan dengan berbagai cara, salah satunya adalah bertatap muka langsung untuk membahas permasalahan mahasiswa dalam menyusun laporan Tugas Akhir. Pada saat ini, dengan perkembangan teknologi informasi yang semakin canggih, maka proses atau kegiatan layanan bimbingan tidak hanya bisa dilakukan dengan cara yang konvensional yakni bertatap muka langsung, tetapi dapat memanfaatkan kecanggihan teknologi informasi dengan cara online sehingga proses bimbingan akan lebih menarik, interaktif dan tidak terbatas ruang dan waktu.

Pada saat ini di Perguruan Tinggi Raharja masih menggunakan metode konvensional dalam proses bimbingan laporan Tugas Akhir kepada para mahasiswa, dimana dosen pembimbing bertatap muka langsung dengan mahasiswa yang bersangkutan. Kekurangan dari proses bimbingan secara konvensional ini adalah terbatasnya waktu bimbingan dikarenakan adanya ketidaksamaan waktu luang yang dimiliki oleh mahasiswa dan dosen pembimbing yang bersangkutan. Hal ini 
menyebabkan proses bimbingan menjadi terhambat dan kurang optimal.

Adapun inovasi baru yang dilakukan dalam menunjang proses bimbingan laporan Tugas Akhir agar berjalan lebih optimal adalah dengan memanfaatkan media online yaitu RinfoDocs. RinfoDocs merupakan salah satu fasilitas pada RinfoDrive yang disediakan oleh Rinfo, sedangkan Rinfo adalah sebuah layanan Google Mail (Gmail) menggunakan platform Google yang disediakan khusus oleh Perguruan Tinggi Raharja untuk Pribadi Raharja.

Dengan memanfaatkan RinfoDocs dalam proses bimbingan laporan Tugas Akhir, maka kegiatan bimbingan dapat lebih efektif dan efisien karena antara dosen pembimbing dan mahasiswa tidak harus bertatap muka langsung. Sehingga bimbingan tidak hanya dilakukan pada waktu tertentu saja, akan tetapi dapat dilakukan kapanpun dan dimanapun tanpa terbatas oleh tempat dan waktu.

\section{PERMASALAHAN}

Dalam proses bimbingan laporan Tugas Akhir baik Laporan Tugas Akhir yang berjalan pada Perguruan Tinggi Raharja masih dilakukan dengan cara konvensional, dapat dilihat dari 2 segi permasalahan yakni dari segi mahasiswa dan dosen.

Dari segi mahasiswa, permasalahan yang sering terjadi adalah penggunaan kertas yang berlebihan, hal ini pun berdampak pada biaya yang dikeluarkan oleh mahasiswa. Seperti contoh pada saat melakukan bimbingan laporan Tugas Akhir, mahasiswa memberikan draftlaporan kepada dosen pembimbing berupa print out untuk dikoreksi. Kemudian dosen pembimbing melakukan pengoreksian pada lembaran draft laporan yang tercetak, sehingga jika terdapat kesalahan dalam penulisan laporan maka mahasiswa diwajibkan untuk melakukan revisi lalu mencetak kembali laporannya yang kemudian diserahkan kepada dosen pembimbingnya untuk dikoreksi lebih lanjut. Hal ini tidak efisien dikarenakan penggunaan kertas yang tidak sedikit dan membutuhkan biaya lebih dalam pencetakan ulang laporan yang telah direvisi.

Dari segi dosen, permasalahan yang sering terjadi adalah jika mahasiswa ingin melakukan bimbingan laporan Tugas Akhir harus terlebih dahulu datang ke kampus untuk menemui dosen pembimbing. Namun tidak jarang dosen yang bersangkutan tidak berada di kampus karena adanya perbedaan antara kesenjangan waktu mahasiswa dengan dosen pembimbingannya, tentu hal ini merugikan mahasiswa karena proses bimbingan tidak berjalan dengan baik.

Dari permasalah yang terjadi, perlu adanya inovasi baru dalam pembelajaran, dalam hal ini adalah proses bimbingan laporan Tugas Akhir baik Laporan KKP, TA, maupun Skripsi pada Perguruan Tinggi Raharja. Sehingga tidak lagi adanya penggunaan kertas yang berlebihan serta lebih praktis dan efisien.

Dari permasalahan tersebut di atas dapat disimpulkan secara detail berdasarakan penjabaran tentang sistem pendukung yang tergambar dalam mind mapping di bawah ini 


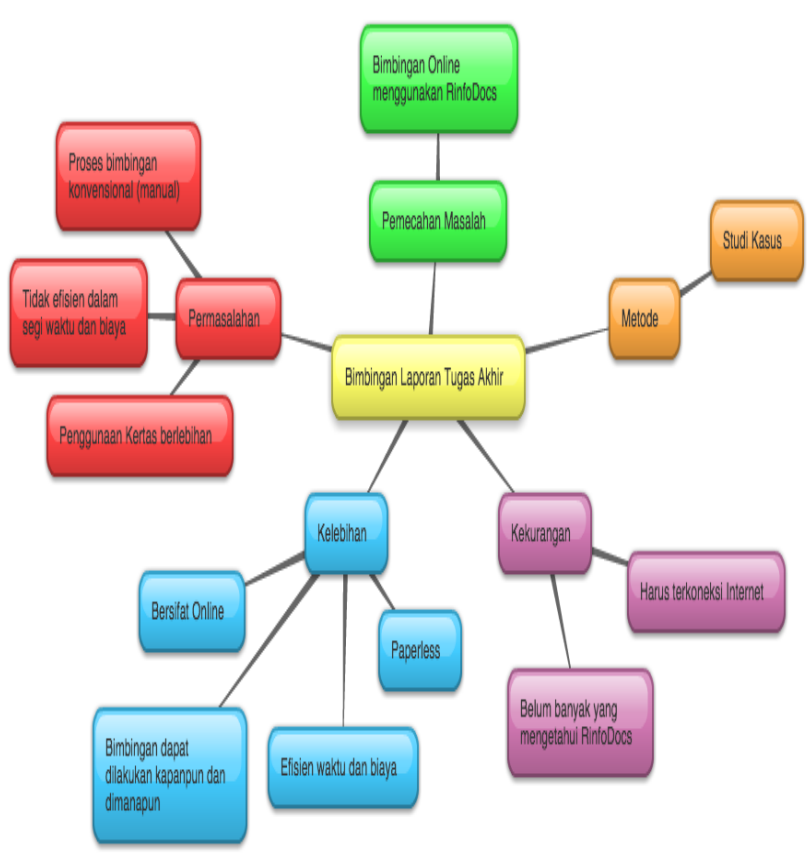

Gambar 1. Mind Mapping proses bimbingan laporan Tugas Akhir

Pada gambar mind mapping diatas menjabarkan permasalahan pada proses bimbingan laporan Tugas Akhir yang kemudian diberikan solusi sebagai pemecahan masalah dengan menggunakan metode-metode tertentu. Mind mapping dibuat untuk mempermudah dalam melakukan analisa.

\section{METODE PENELITIAN}

Dalam melakukan penelitian ini menggunakan metode studi kasus yang ada di salah salah satu perguruan tinggi sebagai lingkup penelitian ini. Penelitian studi kasus bertujuan secara khusus menjelaskan dan memahami obyek yang diteliti secara khusus sebagai suatu kasus. Berkaitan dengan hal tersebut, bahwa tujuan penggunaan penelitian studi kasus adalah tidak sekedar untuk menjelaskan seperti apa obyek yang diteliti, tetapi untuk menjelaskan bagaimana keberadaan dan mengapa kasus tersebut dapat terjadi.
Maka dengan menggunakan metode studi kasus dapat mengetahui lebih mendalam proses bimbingan laporan Tugas Akhir yang sedang berjalan pada Perguruan Tinggi Raharja dan dapat lebih jelas mengetahui permasalahan dan kekurangan dari proses bimbingan laporan Tugas Akhir ini.

\section{LITERATURE REVIEW}

Dalam upaya menerapkan proses pembelajaran online khususnya pada proses bimbingan laporan, hal ini tentunya sudah banyak penelitian yang membahas perihal ini, diantaranya adalah sebagai berikut :

1. Penelitian yang dilakukan oleh Untung Rahardja, Ary Budi Warsito, dan Dini Nurul Suvianti dari Perguruan Tinggi Raharja pada tahun 2012 dengan judul "Penerapan Aplikasi iDINI Sebagai Media Penyimpanan Materi Perkuliahan iLearning Pada Perguruan Tinggi““ menjelaskan bahwa perlu adanya perubahan metode pembelajaran yang dapat menciptakan suasana kelas serta membuat mahasiswa lebih bersemangat. Maka diperlukannya proses yang cepat dan efisien dalam mengakses seluruh data yang banyak terutama dalam media penyimpanan. Integrated Download iBooks in iPad disingkat menjadi iDINI, merupakan media pendukung pembelajaran iLearning yang berupa sebuah aplikasi. Penggunaan aplikasi ini sebagai media penyimpanan bahan ajar materi perkuliahan yang dapat meningkatkan aktivitas mahasiswa dalam pembelajaran iLearning. [3]

2. Penelitian yang dilakukan oleh Aprillita Dwiyani dari Universitas Tanjungpura pada tahun 2013 dengan judul "Perancangan Sistem Pendukung Bimbingan Online Tugas 
Akhir Mahasiswa Program Studi Teknik Informatika"- menjelaskan bahwa bidang pendidikan seperti Universitas juga membutuhkan dukungan sistem informasi dalam peningkatan mutu pelayanan terhadap proses pendidikan, seperti sistem informasi akademik yang terdiri dari banyak proses antara lain perencanaan perkuliahan hingga proses akhir seperti bimbingan skripsi. Maka dirancang sistem pendukung bimbingan online yaitu Aplikasi BIOTA (Bimbingan Online Tugas Akhir) merupakan aplikasi yang bertujuan mempermudah proses bimbingan tugas akhir antara dosen pembimbing dan mahasiswa bimbingannya, dapat menjadi forum komunikasi antara kedua dosen pembimbing dan dapat terpantau pelaksanaan bimbingan tugas akhir tersebut oleh Ketua Program Studi dan Ketua Jurusan. [1]

3. Penelitian yang dilakukan oleh Hani Irmayanti pada tahun 2011 dengan judul "“Pembangunan Aplikasi Bimbingan dan Konseling Online Pada Sekolah Menengah Pertama Negeri 1 Parigi Kabupaten Ciamis" menjelaskan bahwa untuk mempermudah proses bimbingan dan konseling yang lebih baik maka dibutuhkan aplikasi berbasis web agar menghasilkan data dan informasi yang lebih cepat dan akurat. Maka dirancang sebuah aplikasi bimbingan dan konseling secara online di Sekolah Menengah Pertama Negeri 1 Parigi. Aplikasi yang disajikan secara online maka proses bimbingan dan konseling akan lebih menarik, interaktif serta tidak terbatas ruang dan waktu. Tidak hanya itu, para siswa bisa memanfaatkan kecanggihan teknologi Dengan adanya teknik yang baru ini.[2]

4. Penelitian yang dilakukan oleh Untung Rahardja, Khanna Tiara, dan Ray Indra pada tahun 2014 dengan judul "Penerapan Rinfo Sebagai Media Pendukung Untuk Proses Pembelajaran Pada Perguruan Tinggi Raharja" menjelaskan bahwa penerapan Rinfosebagai media komunikai sekaligus alat pendukung dalam proses pembelajaran secara online di Perguruan Tinggi Raharja. Rinfo adalah Gmail yang diadaptasi dari Google Platform, karena berasal dari Google Platform maka Rinfo terhubung pula dengan alat penunjang pembelajaran lainnya, seperti Docs, Drive, Sites, dan alat penunjang lainnya.[4]

5. Penelitian yang dilakukan oleh Andi Susilo dan Yasmiati, mengenai Google AppsUntuk Proses Pembelajaran di Fakultas Teknologi Informasi, Universitas Respati Indonesia. Meneliti tentang migrasi email dan pengimplementasiaan Google Apps for Education untuk memperbaiki proses pembelajaran melalui metode blended learningdi Fakultas Teknologi Informasi, Universitas Respati Indonesia. Pembelajaran tersebut sudah berbasis cloud computing dengan layanan yang telah diaktifkan meliputi Gmail, Google Sites, Google Docs, Gtalk, Google Calendar, Google Groups, Postini Services, dan Google Contacts dengan subdomain fti.urindo.ac.id. Penerapan Google Apps for Education dilakukan di seluruh komponen kampus dan diharapkan akan mengurangi biaya secara signifikan terhadap investasi software dan hardware yang ada di Universitas Respati Indonesia, 
khususnya di Fakultas Teknologi Informasi.[6]

Dari 5 (lima) literature review diatas, sebagian besar adalah membahas perihal pembelajaran yang dilakukan secara online melalui berbagai media. 2 diantaranya membahas mengenai aplikasi dengan platform Google sebagai media pendukung dalam proses pembelajaran, salah satunya adalah Rinfo. Hal ini berkaitan dengan penelitian yang dilakukan, namun pada penelitian yang telah ada sebelumnya membahas secara umum kegunaan dari Rinfo, tidak membahas secara khusus fasilitas yang terdapat pada Rinfo terutama RinfoDocs. Dapat disimpulkan bahwa belum ada penelitian yang membahas tentang "Pemanfaatan RinfoDocs Sebagai Media Penyusunan Draft Laporan Dalam Proses Bimbingan Tugas Akhir Pada Perguruan Tinggi".

\section{PEMECAHAN MASALAH}

Untuk mengatasi permasalahan yang ada, maka diperlukan suatu proses bimbingan laporan Tugas Akhir yang baru. RinfoDocs dapat dijadikan sebagai sebuah solusi untuk mengatasi permasalahan yang telah dijabarkan diatas. RinfoDocs merupakan salah satu fasilitas pada RinfoDrive yang disediakan oleh Rinfo, sedangkan Rinfo adalah sebuah layanan email yang disediakan khusus oleh Perguruan Tinggi Raharja untuk Pribadi Raharja (civitas akademik).

Setiap Pribadi Raharja wajib memiliki email Rinfo, dalam hal ini mahasiswa dan dosen untuk mempermudah proses bimbingan laporan Tugas Akhir. Mahasiswa yang memiliki email Rinfo dapat langsung memanfaatkan fasilitas RinfoDocs yang telah tersedia.

Dengan menggunakan RinfoDocs, mahasiswa dapat menyusun laporan secara online. Kemudian mahasiswa dapat melakukan invite dosen pembimbing yang bersangkutan dengan memasukkan alamat email dosen tersebut. Maksud dari invite dosen pembimbing bertujuan untuk melakukan bimbingan laporan secara online, hal ini dosen dapat mengoreksi langsung laporan mahasiswa dengan cara memblok bagian-bagian yang dinilai kurang tepat atau salah untuk diberikan komentar.

Dalam memberikan komentar, perlu menambahkan tag email yang bersangkutan baik mahasiswa maupun dosen pembimbing. Ini bertujuan agar mahasiswa atau dosen pembimbing tersebut mendapatkan email notifikasi. Adanya email notifikasi ini tentu memberikan kenyamanan khususnya kepada mahasiswa karena dapat dengan mudah mengetahui bahwa laporan yang dibuat telah dikoreksi oleh dosen pembimbingnya. Mahasiswa dapat segera melakukan revisi dan memberikan feedback dengan cara membalas komentar dari dosen pembimbing. Berikut ini adalah contoh dokumen pada RinfoDocs yang telah dikomentari
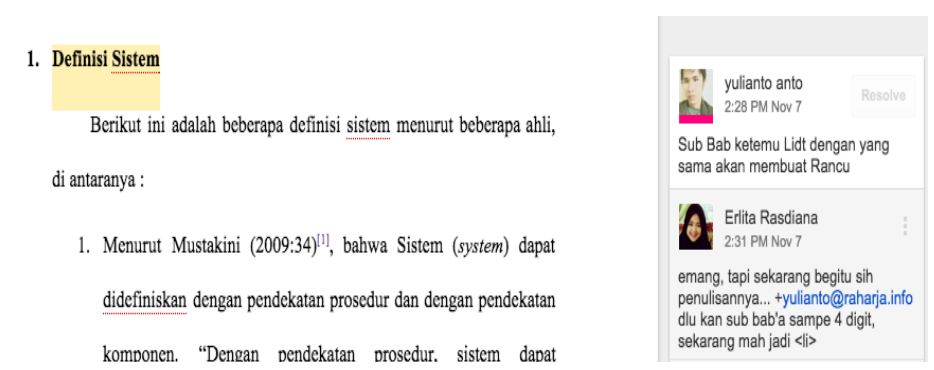

Gambar 2. Contoh dokumen yang dikomentari

Jika adanya kesalahan yang dikomentari akan lebih mudah terlihat, karena bagian yang terblok atau dikomentari tersebut memiliki warna yang berbeda dari bagian yang tidak terblok atau dikomentari. Komentar-komentar dari dosen pembimbing yang mengoreksi terdapat pada bagian yang terpisah yaitu berada pada sisi kanan dari laporan, sehingga komentar tersebut tidak tercampur dengan laporan. 
Untuk memudahkan penjabaran dari penggunaan RinfoDocs, maka dilakukan cara alternatif penggambaran sistem melalui alur flowchart. Di bawah ini merupakan alur dalam penggunaan RinfoDocs yang dapat digambarkan dengan flowchart dan usecase diagram, mulai dari LoginRinfo, Membuat Laporan di RinfoDocs, Share Laporan, dan Memberikan Komentar di RinfoDocs.

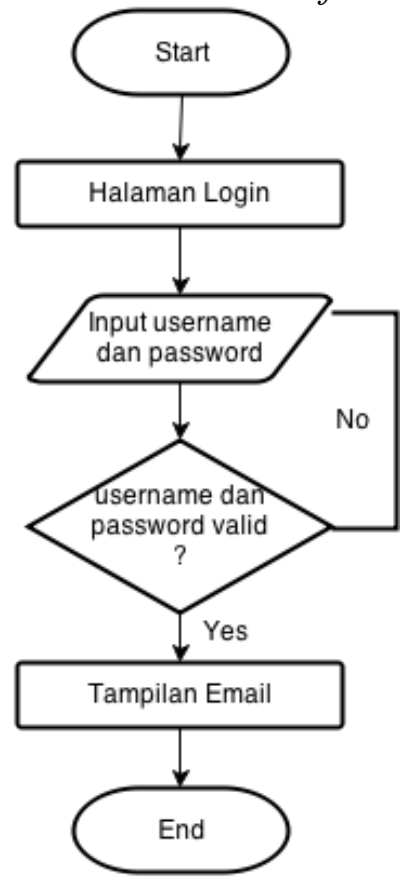

Gambar 3. Flowchart Login Rinfo

Gambar di atas menjabarkan proses login email Rinfo. Dimulai dari tahapan awal yaitu mengunjungi halaman http:/gmail.com. Lalu memasukkan username dan password. Jika username dan password yang dimasukkan valid, maka user berhasil masuk ke halaman email Rinfo, namun jika username dan password tidak valid maka user masih tetap berada dihalaman yang sama dan disarankan untuk mengulang memasukkan akun (username dan password) yang valid.

Flowchart Membuat Laporan di
RinfoDocs

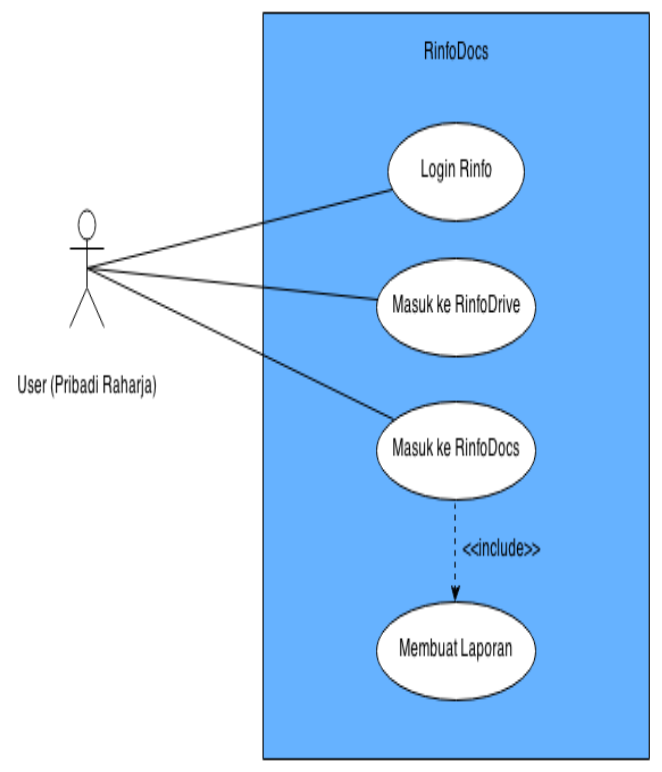

Gambar 4. Usecase Pembuatan Laporan Tugas Akhir di RinfoDocs

Gambar di atas menjabarkan proses pembuatan laporan Tugas Akhir. Langkah pertama adalah melakukan LoginRinfo pada halaman http:/gmail.com/. Jika telah berhasil masuk ke email Rinfo, maka mahasiswa dapat langsung menggunakan fasilitas RinfoDocs pada RinfoDrive dan dapat langsung membuat laporan.

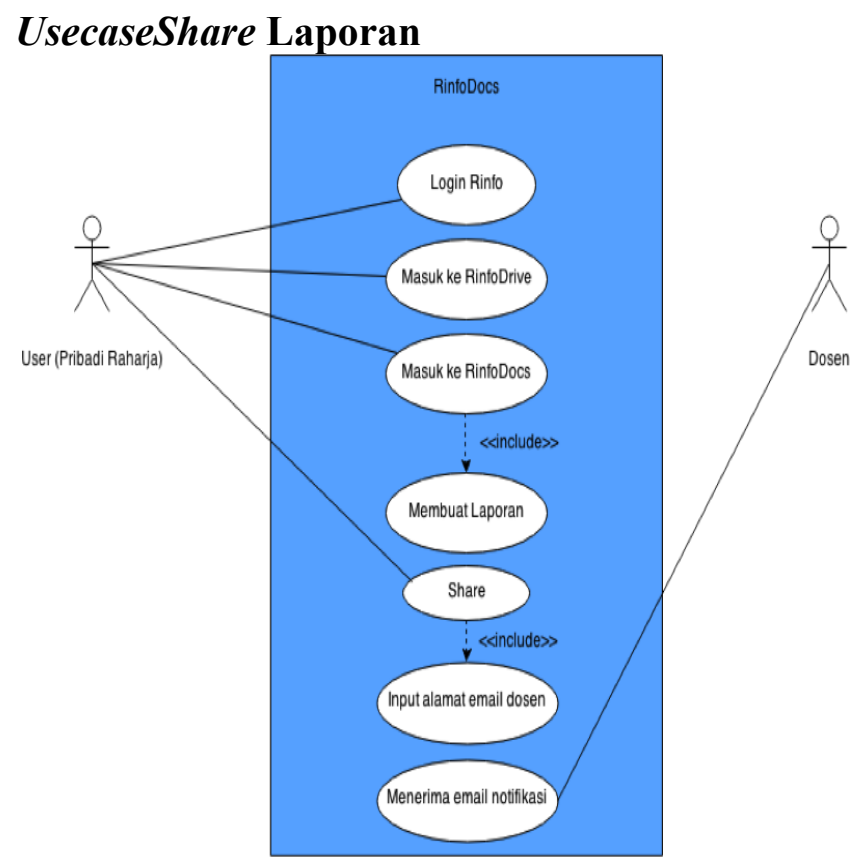

Gambar 5. Usecase Share Laporan 
Gambar diatas menjabarkan proses share laporan pada RinfoDocs yang dilakukan oleh mahasiswa. Langkah awal dalam share laporan ini prosesnya sama dengan langkah pembuatan laporan di RinfoDocs, namun setelah selesai membuat laporan dapat langsung melakukan share dengan menginputkan alamat email dosen pembimbing yang bersangkutan dan kemudian dosen pembimbing akan menerima email konfirmasinya bahwa telah di invite pada laporan laporan yang telah dibuat oleh mahasiswa tersebut.

\section{Usecase Memberikan Komentar di RinfoDocs}

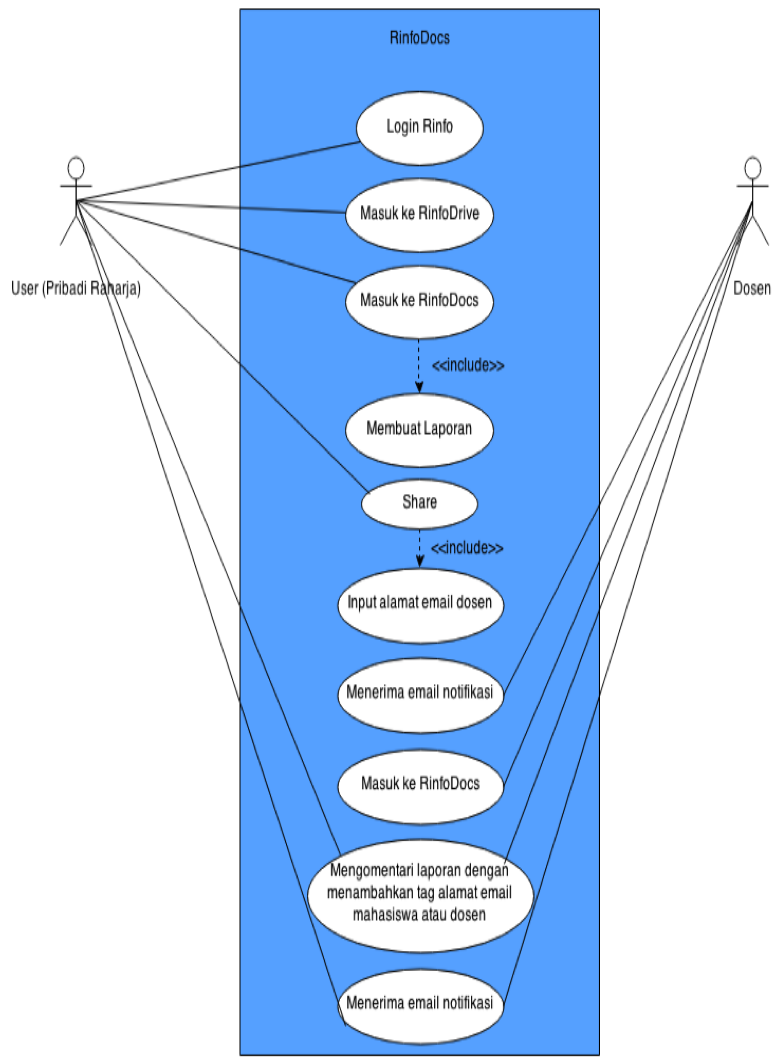

Gambar 6. Usecase Memberikan Komentar di RinfoDocs

Pada gambar diatas menjabarkan tentang proses dalam memberikan komentar pada laporan di RinfoDocs. Namun untuk dapat memberikan komentar, dosen pembimbing yang bersangkutan harus di invite terlebih dahulu dan diberikan hak akses can comment (dapat memberikan komentar). Jika dosen memberikan komentar maka yang membuat laporan tersebut dalam hal ini adalah mahasiswa akan mendapatkan email notifikasi pemberitahuan bahwa dosen telah memberikan komentar.

\section{IMPLEMENTASI}

\section{Tampilan Halaman Login Rinfo}

Pada Halaman Login Rinfo terdapat kotak isian username dan password email Rinfo. Untuk dapat masuk ke dalam email Rinfo, semua Pribadi Raharja wajib menginputkan akun emailnya terlebih dahulu. Halaman Login Rinfo ini dapat diakses pada http://gmail.com/.

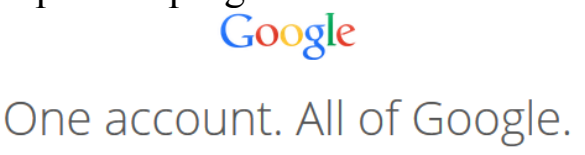

Sign in to continue to Gmail

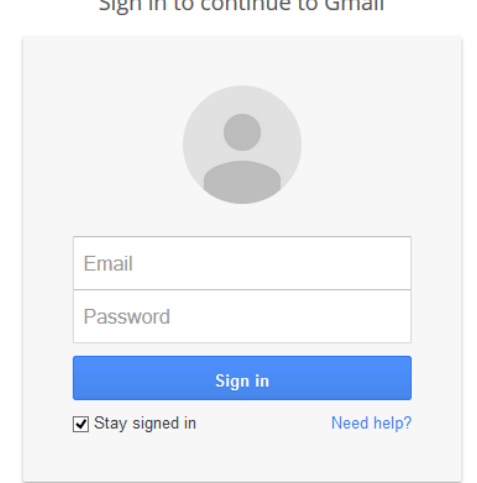

Gambar 7. Tampilan Halaman Login Rinfo

\section{Tampilan Halaman Email Rinfo}

Pribadi Raharja yang telah berhasil LoginRinfo akan mendapatkan tampilan email Rinfo. Pada tampilan email Rinfo ini terdapat tombol untuk Membuat Email, terdapat menu Setting dan RinfoApps, label Pesan Masuk (Inbox), Pesan Terkirim (Sent Mail), Draft, dan lain sebagainya. 


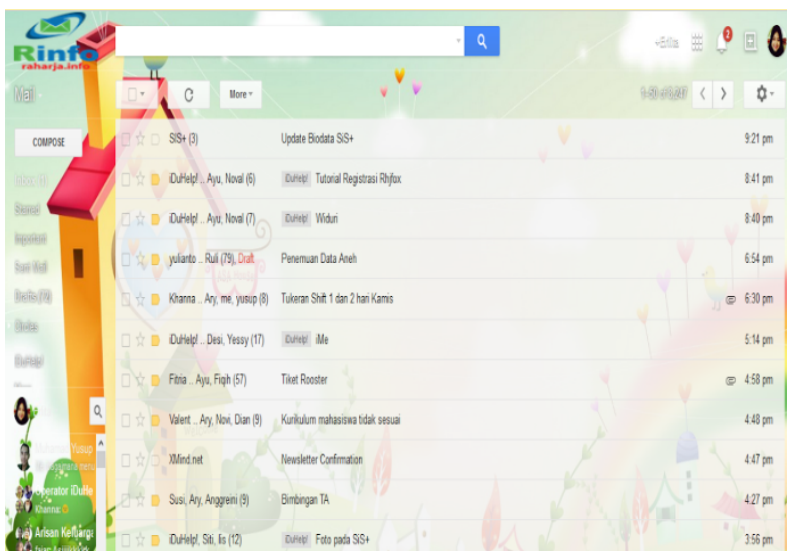

Gambar 8. Tampilan Halaman Email Rinfo

\section{Tampilan Halaman RinfoDocs}

Pada tampilan halaman RinfoDocs serupa dengan tampilan Microsft Word. Namun terdapat sedikit perbedaan, yakni selain berbeda dalam hal pengaksesan, juga terdapat perbedaan lainnya seperti tampilan Ribbon/icon-icon untuk pengaturan tulisan dan halaman, dimana Ribbon/icon-icon pada RinfoDocs lebih sedikit dibandingkan dengan Microsoft Word.

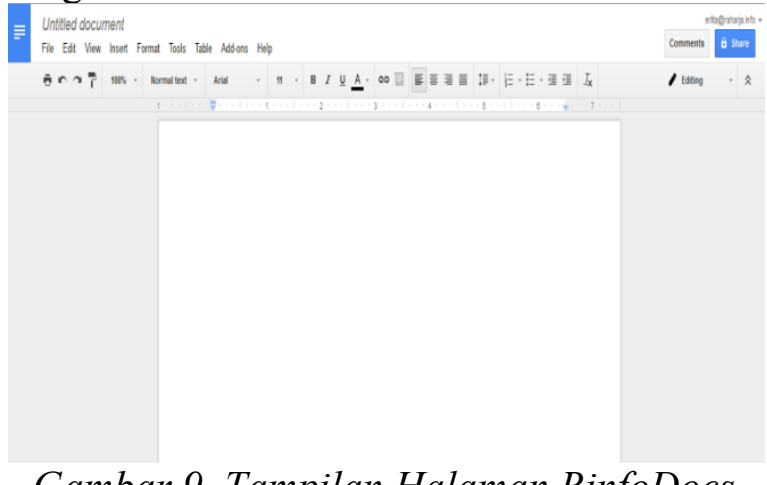

Gambar 9. Tampilan Halaman RinfoDocs

\section{Tampilan Share Laporan RinfoDocs}

Pada tampilan window share laporan RinfoDocs terdapat kotak isian yang digunakan untuk memasukkan daftar user yang ingin diberikan laporan tersebut, atau dengan kata lain laporan yang telah dibuat ingin di share atau dibagikan kepada siapa saja dengan menginputkan alamat email user yang bersangkutan. Lalu terdapat otorisasi atau hak akses untuk user yang telah di daftarkan tersebut, terdapat 3 hak akses yaitu dapat mengedit laporan langsung (can edit), dapat memberikan komentar (can comment), dan hanya dapat melihat (can view).

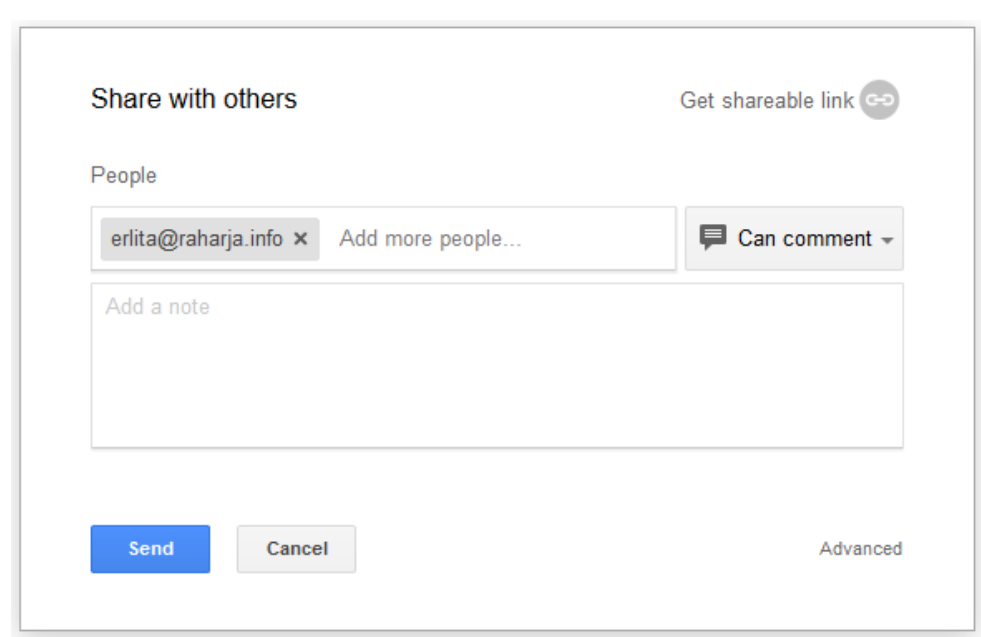

Gambar 10. Tampilan Share Laporan RinfoDocs

Tampilan Komentar Laporan di RinfoDocs

Pada RinfoDocs terdapat sebuah fasilitas untuk berkomentar, dimana komentar yang dibuat akan secara otomatis tampil disisi sebelah kanan lembar kerja sejajar dengan bagian pada laporan yang dikomentari.

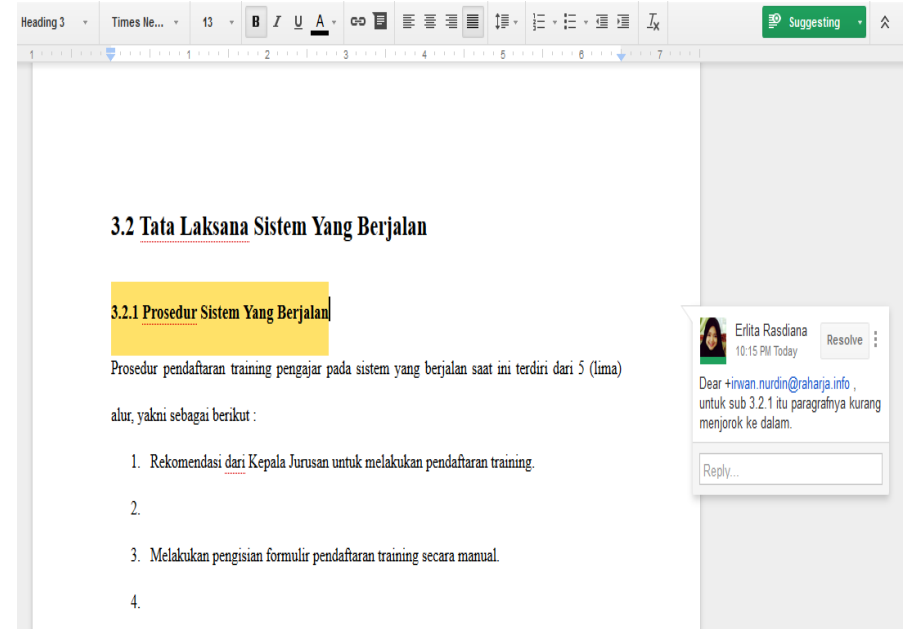

\section{Gambar 11. Tampilan Komentar Kaporan di RinfoDocs}

Adapun kelebihan menggunakan RinfoDocs adalah dapat memaksimalkan proses bimbingan laporan Tugas Akhir antara mahasiswa dengan dosen pembimbing yang 
bersangkutan di Perguruan Tinggi Raharja sehingga lebih efektif dan efisien. Lebih efektif dikarenakan tidak perlu melakukan bimbingan dengan cara menemui langsung dosen pembimbing yang bersangkutan, karena dapat dilakukan secara online dimanapun dan kapanpun. Disamping itu, dapat dikatakan lebih efisien dikarenakan tidak menggunakan kertas yang berlebihan (paperless) dan dapat meminimalisir biaya pengeluaran tambahan mahasiswa untuk mencetak draft laporannya. Dengan kata lain, penggunaan RinfoDocs dalam proses bimbingan laporan Tugas Akhir lebih efektif dan efisien.

Selain memiliki kelebihan, terdapat juga beberapa kekurangan dalam penggunaa RinfoDocsterutama adalah harus tekoneksi dengan internet karena RinfoDocs bersifat online dan hanya dapat diakses apabila terkoneksi dengan internet. Di samping itu, banyaknya mahasiswa yang telah memiliki akun email Rinfo namun belum seluruhnya mengetahui adanya fasilitas RinfoDocs yang sudah tersedia pada Rinfo.

Jumlah pengguna Rinfo sudah mencapai 2.924 pengguna[5], dan dapat terlihat pada grafik dibawah ini :

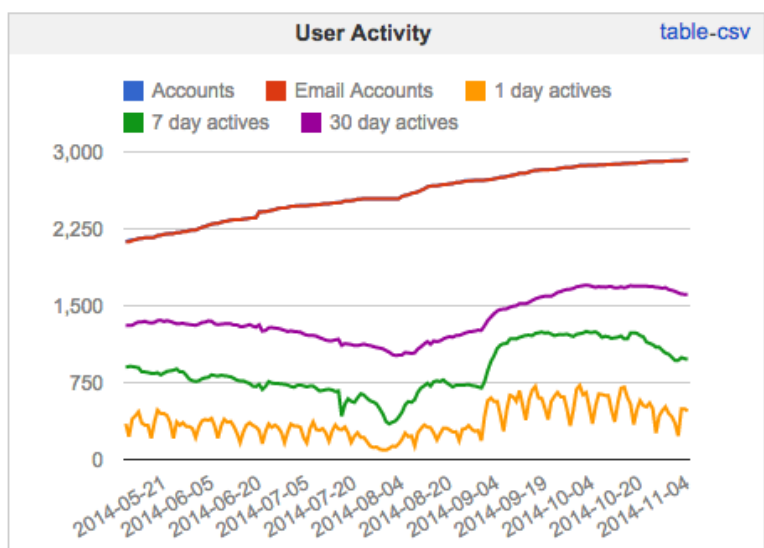

Gambar 12. Statistik Pengguna Rinfo

Pada gambar statistik pengguna Rinfo diatas, menggambarkan tentang jumlah pengguna Rinfo semakin meningkat dan hingga saat ini tercatat mencapai 2.924 pengguna.
Mungkin adanya kekurangan ini dapat dilakukan sosialisasi perihal Rinfo dan fasilitas-fasilitas yang terdapat di Rinfo kepada seluruh mahasiswa dengan bekerja sama para dosen untuk mensosialisasikan dengan salah satu cara memberikan tugas yang berhubungan dengan Rinfo.

\section{KESIMPULAN}

RinfoDocs adalah salah satu fasilitas pada RinfoDrive yang disediakan oleh Rinfo, sedangkan Rinfo adalah sebuah layanan email Gmail menggunakan platform Google yang disediakan khusus oleh Perguruan Tinggi Raharja untuk Pribadi Raharja. Karena menggunakan platform email Google, maka pada Rinfo terdapat fasilitas penunjang pembelajaran seperti Docs untuk pembuatan dokumen, Drive untuk menyimpan berbagai dokumen, Site untuk pembuatan sebuah website, dan lain sebagainya. Hal inilah mengapa adanya sebutan RinfoDocs. Setiap Pribadi Raharja wajib memiliki akun email Rinfo dalam hal ini mahasiswa dan dosen untuk mempermudah proses bimbingan laporan Tugas Akhir. Mahasiswa yang memiliki email Rinfo dapat langsung memanfaatkan fasilitas RinfoDocs yang telah tersedia. RinfoDocs mudah digunakan dan dapat diakses dimanapun dan kapanpun selama terkoneksi dengan internet. Dengan memanfaatan RinfoDocs dalam pembelajaran khususnya proses bimbingan laporan Tugas Akhir, mahasiswa tidak perlu datang ke kampus menemui dosen pembimbing untuk melakukan bimbingan laporan. Dikarenakan dapat dilakukan secara online dengan cara share laporan dari RinfoDocs. Proses bimbingan secara online ini mencerminkan kampus IT dengan memanfaatkan perkembangan teknologi. Selain itu dengan memanfaatkan RinfoDocs juga dapat mengurangi penggunaan kertas yang berlebihan (paperless). Dengan kata lain 
proses bimbingan dengan RinfoDocs lebih efisien dari segi biaya maupun waktu.

\section{DAFTAR PUSTAKA}

1. Aprillita, Dwiyani. 2013. "Perancangan Sistem Pendukung Bimbingan Online Tugas Akhir Mahasiswa Program Studi Teknik Informatika" Universitas Tanjungpura, Pontianak, Indonesia.

2. Irmayanti, Hani. 2011. "Pembangunan Aplikasi Bimbingan Dan Konseling Online Pada Sekolah Menengah Pertama Negeri 1 Parigi Kabupaten Ciamis”. Perpustakaan UNIKOM : Bandung.

3. Rahardja, Untung, Ary Budi Warsito, Dini Nurul Suvianti. 2012. "Penerapan Aplikasi iDINI Sebagai Media Penyimpanan Materi Perkuliahan iLearning Pada
Perguruan Tinggi”. Jurnal CCIT Vol.6 No.1. Tangerang : Perguruan Tinggi Raharja.

4. Rahardja, Untung, Khanna Tiara, dan Ray Indra Taufik Wijaya. 2014. "Penerapan Rinfo Sebagai Media Pendukung Untuk Proses Pembelajaran Pada Perguruan Tinggi Raharja". Jurnal CCIT Vol.8 No.1 September 2014. ISSN: 1978 - 8282. Tangerang : Perguruan Tinggi Raharja.

5. Site iMe Rinfo. 2014. http://eco.ilearning.me/search-rinfouser/. Diakses pada tanggal 7 November 2014 pukul 13:00 WIB.

6. Susilo, Andi. Yasmiati. "Google Apps Untuk Proses Pembelajaran di Fakultas Teknologi Informasi (FTI), Universitas Respati Indonesia“. ISSN: 1907-5022. 